\section{Nonlinear dynamics could help in battle for sustainability}

[ROME] The study of nonlinear dynamics offers "unexplored possibilities" for overcoming the current "stalemate" in knowing how to face the many threats facing modern civilization. So concludes a statement issued following a study week organized last month by the Pontifical Academy of Sciences.

The statement was drawn up by Marcelo Sanchez Sornod, chancellor of the academy, and Vladimir Keilis-Borok, of the International Institute of Earthquake Prediction Theory and Mathematical Geophysics in Moscow. It has been put forward as a contribution to the deliberations of the World Conference on Science.

The authors say that the meeting extended a wide range of debates on the applications of nonlinear dynamics to critical phenomena. It also identified areas in which the resources offered by such a form of analysis "have not been fully exploited".

In particular, the meeting suggested that one area might be the study of scenarios of transition to "unsustainability", and ways of responding to them. "Such a study may help to overcome a lack of interest in this question, something which was criticized by several speakers," say the authors of the statement.

"We should engage neither in Cassandralike announcements of future catastrophes, nor in any irresponsible optimism," the authors write. "Today, in the face of the global complexity of our contemporary context, the human being, more than ever before, is called upon to find that right kind of rationality which will achieve survival and sustainability through the application of new and well-deployed practical criteria." Full text: http://helix.nature.com/wcs/m16s.html

\title{
India's science funds 'safe' despite fall of government
}

[NEW DELHI] India's senior science administrators say that the fall of the government last week is unlikely to have a significant impact on science and technology activities, provided that the budget is passed without cuts by the new government.

The 1999-2000 budget was presented by the coalition government led by the Bharatiya Janata Party (BJP) on 28 February (see Nature 398, 4; 1999). The budget must be approved by parliament within 75 days, but the government was defeated in parliament in a confidence motion last week. Opposition parties led by the Congress party are likely to pass the budget without making major changes.

"The BJP had given us an excellent budget for science this year and we never had it so good," says Ragunath Mashelkar, chief of the
Council of Scientific and Industrial Research. "I hope the budget will be passed and that there will not be any cut."

Some observers say, however, that, although the budget for science is unlikely to be revised, the allocation for the nuclear weapons programme - a top priority of the BJP government - may be cut by the Congress party if it forms the government.

Valangiman Ramamurthi, secretary of the ministry of science and technology, says the change in government is of no significance as far as India's participation in the World Conference on Science is concerned. India's position at the conference has been decided, although "who will lead the delegation is something we have to wait for until a new government is formed".

Full text: http://helix.nature.com/wcs/b31.htm

\section{Canadian plea for freedom of information}

[OTTAWA] A group of graduate students at Carleton University in Ottawa, Canada, has produced a set of 21 'principles for science', intended as a contribution to the discussion leading up to the World Conference on Science, and described as "a declaration of interdependence for the 21 st century".

The principles endorse the concept of scientific freedom - including the freedom to publish research results and attend conferences at home and abroad while acknowledging that such freedom "is neither absolute nor unfettered". They also argue for a better, long-term commitment to basic science in all countries.

They state that, contrary to trends towards commercialization, scientific knowledge should be disseminated freely and openly. "Developing countries, in particular, require affordable and ready access to research results if they are to prosper in the next millennium."

The students are participants in a graduate seminar on science, technology and international affairs, led by Gerald Graham of the Norman Paterson School of International Affairs.

One of the more controversial suggested principles is that "the public has a right to be involved in every stage of the scientific process, from the conception of a project to its ultimate completion". Full text: http://helix.nature.com/wcs/a25.html

\section{Intellectual rights 'must serve the needs of developing countries'}

[PORT OF SPAIN] The international community needs to ask itself whether current forms of intellectual property protection are appropriate for the needs of the developing world, says Kamla PersadBissessor, minister of legal affairs for Trinidad and Tobago.

According to Persad-Bissessor, in the rush to appear developed, developing nations may have emphasized the acquisition of consumer durables rather than building the infrastructure that could have sustained further development. In doing so, she says, they took on the products of the research of developed nations without doing the research themselves, often feeling free "to borrow, copy and plagiarize the knowledge of developed nations".

In developed countries, she points out, the growth of intellectual property protection occurred alongside technological and other developments. But, in developing countries, intellectual property protection has in a sense been imposed by the need of the first world to protect its interests.

"This provides an interesting challenge

Æิ๑ 1999 Macmillan Magazines Ltd to the legislators of developing nations, to ensure that model legislation provided obligingly by the world Intellectual Property Organization is appropriately tailored to the needs of the local creators and inventors," said Persad-Bissessor.

Speaking at a workshop organized by the Caribbean Academy of Sciences, she said that certain provisions might have to be modified, or new areas of protection developed within the legislation, to meet the need for development. Full text: http://helix.nature.com/wcs/c11.html 